\title{
Fingernem forebygger
}

\author{
Professor Børge Ytterstad har gitt seg som kirurg, men fortsetter å forske på forebygging \\ av ulykker. Han bare tar det litt mer piano.
}

«Vi kan møtes for intervju på onsdag. En kjapp prat, litt kinamat og så må jeg videre. Det er fotballkamp på puben!»

E-posten fra Børge Ytterstad noen dager i forveien er ikke til å ta feil av. Champions League-kampen $m a ̊$ han ha med seg. Kanskje ikke så rart, all den tid den pensjonerte kirurgen opp gjennom årene selv har sprunget rundt på forblåste grusbaner i Nord-Norge og jaget livredde motstandere til skogs. Langbent, knoklete og kompromissløs, skal ryktene ha det til. Mer om det senere.

- I det hjørnet har jeg spist mange middager, sier Ytterstad og peker med pianofingrene sine.

Vi sitter på en kinesisk restaurant i Tromsø sentrum, og den høyreiste harstadværingen med det kritthvite håret er i gang med å fortelle om forskningen sin.

- Det ble et slags ritual etter å ha fått en artikkel publisert: Ned hit, bestille en flaske Jacobs Creek og kanskje and i sursøt saus. Herlig!

Det er blitt en del middager på kinarestauranten for Børge Ytterstad gjennom et langt forsker- og kirurgliv.

Som Norges eneste professor i skadeforebygging har han publisert flerfoldige artikler om skaderegistrering og forebygging av ulykker. Han har bidratt til utbygging av gang- og sykkelveier i nærmiljøet og har veiledet flere byer i å bli WHO-sertifiserte «trygge lokalsamfunn».

I dag har Ytterstad gitt seg som urolog, men han er fortsatt aktiv i forskningen - mest som helsefaglig veileder i regionens ulykkesanalysegrupper (UAG), som bedriver dybdeanalyser av samtlige dødsulykker på nordnorske veier. Han ser gjennom obduksjonsrapporter og blodanalyser fra trafikkofre.

- Det er mye tragisk hos de unge. Flere blodanalyser viser innhold av alkohol, amfetamin eller GHB. Vi har fortsatt en vei å gå, og det er størst potensial i å forebygge trafikkulykker hos unge menn $i$ alderen 18-24 år, sukker han.

\section{Registrerte mørketall for ulykker}

Interessen for forebygging kom etter noen hektiske år som ung kirurg og som leder av den lokale velforeningen. I 1980-årene så han at politiets skaderegistre var ufullstendige og startet på eget initiativ opp med skaderegistrering. I 1995 resulterte det i en doktorgrad.

- Jeg jobbet i Harstad som generell kirurg og tok imot mange av disse pasientene - barn med tredjegradsforbrenninger fordi de hadde fått glovarm kaffe over seg, syklister som ikke hadde brukt hjelm og hadde fått hodeskader og eldre som hadde sklidd i dusjen og pådratt seg lårhalsbrudd. Jeg bodde nær en riksvei hvor det daglig var barn på vei til skolen. Forebygging er en bedre langsiktig plan enn behandling, tenkte jeg. Noe måtte gjøres

\section{«Forebygging er en bedre langsiktig plan enn behandling»}

for å få bedre samsvar mellom det politiet rapporterte og det helsevesenet registrerte. Det var store mørketall, sier den pensjonerte legen.

\section{Tøft møte med Oslo}

Lege var det forresten en ambisiøs mor som bestemte at han skulle bli.

- Jeg kom hjem en dag og så at det lå et brev på bordet. Det var fra Universitetet i Oslo og var et tilbud om plass på medisinstudiet der nede.

Ytterstad slår ut med armene: - Jeg visste ingenting om det, ante ingenting om søknaden og fikk vite at det var min mor som hadde søkt meg inn!

Den samme moren hadde for øvrig noen år i forveien også sendt Ytterstad på high school i USA som utvekslingstudent. - Jeg var sjanseløs mot henne! Ja ja, OK, tenkte jeg. Jeg får prøve medisin.

Han pakket fotballsko og jaktstøvler og satte seg på sjøflyet ned mot hovedstaden.

- Møtet med Oslo var tøft. Vi med nord- norsk dialekt fikk streng beskjed om å snakke norsk, sier han, og kikker seg lurt rundt. - Så vi snakket demonstrativt enda bredere, gliser han.

Innimellom leseøktene på universitetet levde harstadværingen det gode liv med beintøffe studentfotballkamper, jaktekspedisjoner og jobber som taffelpianist på både privatfester og i store brylluper.

\section{Øver på pianoet hver dag}

- Pianoet har vært min følgesvenn siden femårsalderen.

Ytterstad er (nesten) selvlært pianist på høyt nivå. Han ga ut sin første CD-plate Just Friends for et par år siden.

I sin doktoravhandling smuglet han inn fem låttitler fra jazzens verden og fremførte disse i den tilhørende festmiddagen, til stor glede for gjestene.

Han gestikulerer akkorder og trommer på bordet mens han prater om sin største lidenskap. - Jeg øver hver eneste dag. Spiller på ekte elfenbenstangenter, på et piano som jazzlegenden Duke Ellington har spilt på under et norgesbesøk. Det er jo en inspirasjon i seg selv, sier han, og nynner en strofe.

Som vordende pianist gikk Ytterstad i lære hos en apotekerfrue i Harstad i et år, men ga seg fort.

- Jeg hatet det som pesten. Det første hun gjorde var å sjekke om jeg hadde skitne negler og satte meg ned en karakter i orden. Og så sprang hun inn og ut av stuen fordi hun hadde sin gamle mor liggende på et kott. Damen lå åpenbart for døden og trengte pleie. Det var uhyggelig, egentlig. Døden var i nærheten!

Han rister lattermildt på hodet, og tar en bit av svinekjøttet. I glasset er det ikke Jacobs Creek, men krystallklart nordnorsk fjellvann. - Jeg kommer fra min årlige tur på Kanariøyene, og da lar jeg alltid hepatocyttene hvile i februar, smiler han lunt.

For niende år på rad arrangerte Ytterstad denne vinteren en solidaritetskonsert i den rolige havnebyen Arguineguín på sørkysten av Gran Canaria, med blant andre Åge Aleksandersen på programmet.

- I år samlet vi inn 85000 kroner til et 


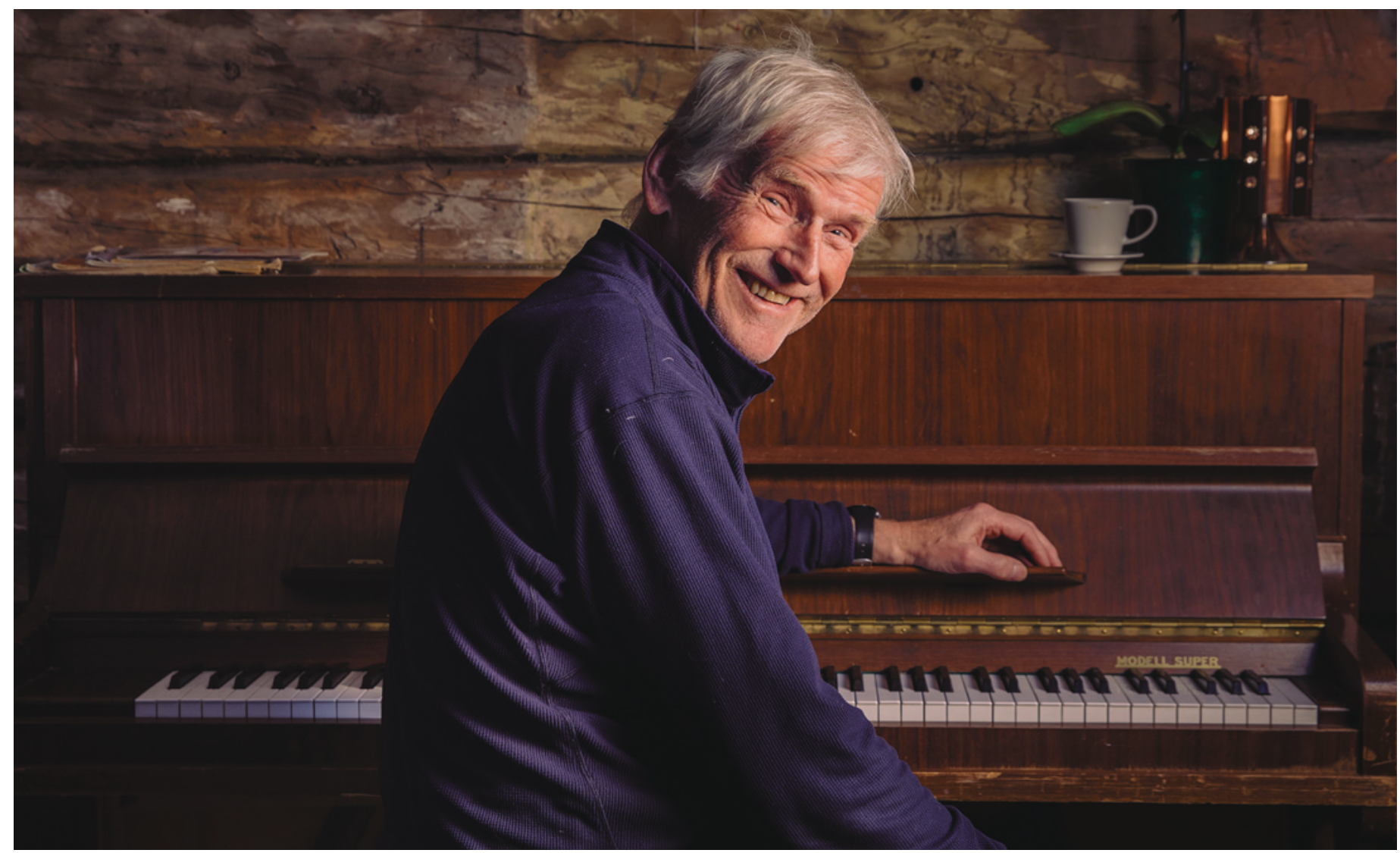

Pensjonert urolog Børge Ytterstad er Norges eneste professor i skadeforebygging. Han bruker flere timer hver dag ved pianoet. Foto: Marius Fiskum

\section{Børge Ytterstad}

Født 1943 i Harstad

- Cand.med. Universitetet i Oslo, 1968

- Turnustjeneste, Tromsø og Harstad, 1968-70

- Spesialist i generell kirurgi, 1977

- Spesialist i urologi, 1993

- Ph.d. ved Universitetet i Tromsø, 1995

- Professor ved Universitetet i Troms $\varnothing$, 2006

- Det nytter-prisen fra Helse- og sosialdepartementet, 1995

- Karl Evangs pris for helseopplysning. 1997

- AEresborger av Harstad, 1998

- Gullnålen fra Trygg Trafikk, 2015

- Formann i European Safe Community Network 2010-14 proteseverksted i Gaza. Det føles godt, forklarer han og lener seg frem med en alvorlig mine: - I rapporten fra 2016 kommer det frem at $70 \%$ av de 2640 klientene til proteseverkstedet var barn under 15 år. $70 \%$ !

Ytterstad kikker tomt ut av vinduet.

- Det er sterke saker.

Engasjementet for barn har alltid vært sterkt.

\section{Halverte antall brannskader}

Hjemme i Harstad allierte han seg tidlig med helsesøstrene for å forebygge brannskader hos barn.

- Som kirurg på sykehuset hadde jeg jo ansvaret for disse problemene. Sykehistoriene var forbausende like: En nysgjerrig småtass lurte på hva som kokte på komfyren, strakte seg opp etter kasserollen, veltet den - og fikk kokende vann i ansiktet og på brystet. Hvordan kunne dette motvirkes? Jo, komfyrvern, informasjon til foreldre gjennom helsesøstrene og flere slike tiltak.

Kampanjen Ytterstad satte i gang i Harstad førte til en halvering av antall brannskader hos barn i alderen 1-4 år. Trafikkskadene ble redusert med $27 \%$, brudd etter fall hos eldre med $26 \%$.

Siden har han forelest og understreket for kolleger om viktigheten av komfyrvern, sykkelhjelm, antisklimatter i dusjen og så videre.

Ytterstad manet rørleggere til å skru ned varmen på varmtvannsberedere fra $65^{\circ} \mathrm{C}$ til $55^{\circ} \mathrm{C}$. - Det er nok til å kverke legionellabakterien, men mye tryggere for huden. Ved $65^{\circ} \mathrm{C}$ tar det tre sekunder å pådra seg en tredjegradsforbrenning, ved $55^{\circ} \mathrm{C}$ tar det 30 sekunder. Det er verdifull tid - og et enkelt tiltak, forklarer han.

Han har pekt på svensk forskning som viser at én krone brukt til skadeforebygging kan gi en uttelling for samfunnet i størrelsesorden 20-40 kroner.

- Du som jobber så mye med ulykker, er du selv en forsiktig type?

Ytterstad myser ut av vinduet. - Egentlig ikke. Jeg drar jo ut på sjøen alene for eksempel.

- En anonym kollega mener du er blitt så engstelig at du ikke beveger deg til utedoen på hytta uten hjelm på hodet?

- Ha-ha! Ikke hør på den gjengen. Jeg går til og med på jakt alene noen ganger, men også med guttegjengen fra gamledager.

Ytterstad er nesten selvforsynt med mat på sitt lille bruk i Ervika, like utenfor Harstad. 


\section{Sterkt knyttet til naturen}

Det sies at knapt noen annen lege i Norge er så opptatt av jakt og fiske som ham.

- Jeg er sterkt knyttet til naturen og ressursene her oppe. Jeg er en skikkelig heimføding som ville rett hjem til mor etter endt studium sørpå, forklarer han. Derfor gikk det et lettelsens sukk hos medstudentene da cand.med. Ytterstad trakk nummer to i valg av turnussted.

- Det var beinhard konkurranse om å få turnusplass på sykehusene ved Oslofjorden, men alle visste at jeg ville hjem til Harstad, sier han, og legger til: - De hadde vel skjønt det da de så at jeg slengte meg på militærflyet nordover hver eneste jaktsesong. Jeg betalte jo bare 15 kroner i forsikring, så fikk jeg en svinbillig tur nordover, smiler han.

Turnustjenesten i nord ble starten på en lang kirurgisk karriere - først som genrell kirurg, så overlegeopplæring i Finnmark, senere ble det subspesialisering innenfor urologi. I flere tiår var han overlege ved sykehuset i Harstad.

- Jeg har alltid vært fingernem og praktisk anlagt. Og det må jeg få understreke: Selv om det var min mors påfunn at jeg skulle studere medisin, har jeg aldri angret.

Han mener et hektisk, vaktdominert yrkesliv har skapt et behov for å leve livet på andre arenaer når man kan.

- Man må jo leve litt, ikke bare gå vakter. Spille fotball, spille piano og nyte livet. Det er mye man bør prøve før man flytter inn i den siste leiligheten med torv på taket, smiler han lurt.

\section{Sjekket opp kona med appelsin}

Kona, fysioterapeuten fra beste vestkant i Oslo, sjekket han opp ved hjelp av en appelsin på et morgenmøte ved kirurgisk avdeling på sykehuset i Tromsø.

- Man trenger jo ikke mer. Ikke ta damene med ut på restaurant og skjenk dem med vin. Vær ærlig og tilby dem en halv appelsin, sier han kontant.

Kona var angivelig ikke interessert i den lekre Ford Mustangen som Ytterstad hadde kjøpt med vikarlegepenger fra Sverige.

- Nei, nei, nei. Den virket ikke på draget. Da sendte nok jaktstøvlene et bedre signal, smiler han.

Og selv om han og kona i dag lever et rolig liv på småbruket, er han fortsatt aktiv

\section{«Selv om det var min mors påfunn at jeg skulle studere medisin, har jeg aldri angret»}

forsker. Han har det siste året engasjert seg sterkt i det han mener er underrapportering av skader.

\section{Bekymret for fagområdet sitt}

- Fagområdet skadeepidemiologi harnærmest stagnert siden «gullalderen» i 1980-90-årene. Lite er publisert nasjonalt siden 2003 fordi vi ikke har gode nok data og fordi skaderegistreringene vi før hadde ved fyrtårnsykehusene i Stavanger, Drammen og Trondheim er lagt ned. I perioden 1985-2003 brukte man disse sykehusene i tillegg til Universitetssykehuset Nord-Norge i Harstad for å registrere skader. Egne sekretærer ble ansatt og lokale data ble brukt til lokale analyser og målrettet forebygging.

I 2003 ble ordningen lagt ned. Det ble for dyrt, mente Helsedirektoratet.

Ytterstad mener dagens måte å samle inn skadedata på er mindre representativ.
- Man bruker et såkalt felles minimum datasett, et nedskalert variabelsett med flere mangler. Man registrerer for eksempel antall syklistskader som behandles, men ikke om det var kollisjon med bil eller utforkjørsel. Slike variabler fortsatte vi å registrere i Harstad, og vi sitter derfor på en unik database, forklarer han.

Derfor satte han også kaffen i halsen da han så Helsedirektoratets estimater for antall skader behandlet $i$ spesialisthelsetjenesten i perioden 2011-15.

- De tallene viste rundt 300000 behandlede skader årlig, noe som er langt under våre tall fra Harstad. Våre estimater, og estimatene i en nasjonal rapport fra 1992, ligger på 400 000-500 000. Da skjønner man at noe er feil med den nye metoden, sukker han.

Han er bekymret for at tallene blir brukt som argumenter når nedlegging av akuttkirurgi ved lokalsykehus skal diskuteres.

- Vårt mål er å fortsette å få nye data på bordet. Jeg trives godt med det, man må jo holde hodet i gang!

Den høyreiste kroppen holder han i gang med roturer og jaktturer i terrenget.

Han har fått kritikk fra jaktkompisene for stadig oftere å søke til jaktmarkene i NordSverige, hvor rypetettheten er større og liene slakere.

Merker han alderen i de en gang så kvikke fotballbena?

- Formen min er på topp! Det er bare bikkja som er blitt så dårlig til bens, ler han og forlater bordet.

Han har jo tross alt en fotballkamp å rekke.

\section{Martin Hotved}

martin@hotvedt.no

Barne- og ungdomsavdelingen

Universitetssykehuset Nord-Norge 